\title{
INVESTIGATING THE APPLICABILITY MAGNITUDE OF THE LEECH'S MODEL OF STYLISTICS ON DYLAN THOMAS'S POEM "DO NOT GO GENTLE INTO THAT GOOD NIGHT"
}

\author{
Abd-Al-Hameed Mustafa Mahmoud Jabsheh ${ }^{\mathrm{i}}$ \\ Lecturer, Department of Languages, \\ Palestine Technical University Kadoorie (PTUK), \\ Tulkarm Campus, \\ Palestine
}

\begin{abstract}
:
The aim of this study was to investigate the applicability magnitude of Leech's model of stylistics on Dylan Thomas's poem "Do Not Go Gentle into That Good Night", and by the same token to investigate its credibility to uncover additional layers of the meaning and message of this poem. To achieve the aim of this study, the researcher followed a qualitative analytical methodology which was applied on the available related literature, but in a survey-like orientation, and, in addition, a discretionary application, by the researcher, to the three maxims (cohesion, foregrounding, and cohesion of foregrounding) of the Leech's model of stylistics on Dylan Thomas's poem "Do Not Go Gentle into That Good Night". Findings of this study have confirmed the applicability, suitability, and credibility of Leech's model of stylistics to Dylan Thomas's poem "Do Not Go Gentle into That Good Night", and that this application resulted in a wider magnitude to interpret the poem as well as a tighter grasp of its universal meaning and touching message. Conclusions of this study have highlighted the credibility of Leech's model of stylistics to reveal the pragmatic facets of the message that a given author of a literary text is trying, consciously or sub-consciously, to communicate with the readers or recipients. As a result, this study came up with a set of related recommendations and conclusions.
\end{abstract}

Keywords: applicability, Leech's model, cohesion, foregrounding, cohesion of foregrounding, Dylan Thomas poetry, "Do Not Go Gentle into That Good Night", stylistics, linguistic, deviation, parallelism

\section{Statement of the problem}

This research investigates the area of closeness in between the Leech model of stylistics at one end, and Dylan Thomas's poem "Do Not Go Gentle into That Good Night" at the other end: Leech's model of stylistics, which consists of three pillars in the form of cohesion, foregrounding, and cohesion of foregrounding, represents a linguistic approach that facilitates the knowledge of how

i Correspondence: email ptc2004w@hotmail.com; a.aljabsheh@ptuk.edu.ps 
language works within a given a text, how the message of a text is communicated through the author's selection of language patterns and linguistic tools, and how it is possible to decipher the encoded meaning within a given text depending on its linguistic construct and components; while Dylan Thomas's poem "Do Not Go Gentle into That Good Night", as found by the previous available literature, and as the case is with all Dylan Thomas's poetry, represents a unique linguistic sphere with its exceptional linguistic craft and format, as well as its universal theme and message that are able to reflect some important facets of human existence. By the same token, and as concluded by the previous available literature, it should be added that approaching and interpreting Dylan Thomas's poetry is generally not an easy task and, at the same time, a daring endeavor due to its unique linguistic weave and the extraordinary craft; as a result, this research proposes that Leech's model of stylistics is applicable to this poem and that this application can reveal the unique linguistic repertoire of this poem as well as some of the most compacted dimensions of its meaning and its universal message that, the researcher believes, are brilliantly encoded within the linguistic matrix of this poem. Dylan Thomas's poetry has been dealt with by a sum of previous literature, and the poem "Do Not Go Gentle into That Good Night" has also been approached by some other previous research, but this kind of encounter, as the researcher has found, is professedly lacking a methodical orientation, and normally results in a scattered and unassembled cognitive digest of the meaning and the message encoded within the lines of this poem.

\subsection{The significance of this study}

The significance of this study, as far as what the researcher has found within the available related literature, lies in the fact that it is the first of its type to investigate the applicability magnitude of Leech's model of stylistics to Dylan Thomas's poem "Do Not Go Gentle into That Good Night"; the importance of this poem falls in the fact that it acts like a representing linguistic model of Dylan Thomas's poetry as a whole which, as stated by previous research, stands for a return to the classics of the poetics of the English language.

Another facet to the significance of this study is that it can focus the attention on the credibility of leech's model of stylistics as a connected unified approach towards dealing with different literary texts, its reliability to reveal and interpret most dimensions of meaning related to a given literary text, its suitability to communicate the message of such given texts, and its applicability as a method of teaching the stylistics, aesthetics, and poetics of the literary text; moreover, this study also orients the attention to the three maxims of leech's model of stylistics (cohesion, foregrounding, and cohesion of foregrounding) as to be effective teaching-learning tools to teach various linguistic aspects of the English language; additionally, this study also orients the attention to these three maxims of the Leech's model of stylistics as a means of communicating and comprehending the pragmatic dimensions of the message of a literary text.

\section{Introduction}

In line with the sum of the available related research, (Bodine, 1992; Leech, 1965; Benham, 1996; Hasan \& Halliday, 1976; McIntyre, 2003; Simpson, 2004; Leech, 2007; Miššíková, 2007; Yeibo \& 
Akerele, 2014; Leech, 2014; Ayars, 2016; Leiden: Brill, 2013; Liu, 2017, Yemets, 2019; Leech \& Short, 2007; Short, 1996 ; Douthwaite, 2000; Short, 2018; Peer \& Hakemulder, 2006; Ediyono \& Ali, 2019; \& Miall \& Kuiken, 1994), it can be stated that Leech's model of stylistics stands for a comprehensive approach of using linguistic description and techniques in order to decode, analyze, decipher the meaning and message of a literary text, and, then, boost the capacity to interpret such a meaning and message; Leech's model consists of three pillars :cohesion, foregrounding, and cohesion of foregrounding: cohesion refers to the visible linguistic signals through which the text is weaved and defined, the explicit unity that exists within the structure of the text, and how each element within the text relate to and integrate with other elements in a tangible and a well-organized linguistic recipe; cohesion, as a stylistic device, exploits various linguistic elements such as grammatical, lexical, phonological, and other semantic means in order to connect each sentence internally and then connecting sentences together into larger units such as paragraphs or chapters; and, in addition, takes different shapes and layers within a text. The second pillar of Leech's model of stylistics is foregrounding which can be defined as the use of unexpected combinations that may occur in all linguistic levels within the text, and can be textually achieved through both deviation and parallelism: deviation, represents a qualitative facet through which language code, scheme, rules and norms are consciously or subconsciously, focused on, violated, breached, broken, and disobeyed, by the author, to yield a special, an unexpected, an irregular, and to some extent, an odd linguistic reality and special facets of meaning and interpretation; deviation can be lexical, grammatical, phonological, graph logical, semantic, dialectal, of register, and of the historical period; but, parallelism, on the other hand, represents the quantitative facet of foregrounding which can be textually manifested through repetition of some foregrounded linguistic features in a calculable matrix. The third pillar of Leech's model of stylistics is labeled as the cohesion of foregrounding which refers to how the different foregrounded elements are implicitly connected together in a given text, and how they work together within their underlying network to serve a specific theme and a special meaning.

The importance of Leech's model of stylistics, in accordance with the available related research (Shklovsky (1921), Leech (1965), Leech (1990), Douthwaite (2000), Rashid (2001), McIntyre (2003), Rifqi (2010), Leech (2014), Raj (2016), Awonuga, Chimuanya \& Meshioye, (2018), Short (2018), Ediyono \& Ali (2019), Yemets (2019), Haynes, Haynes, Habeshaw, Gibbs \& Habeshaw (2020)), lies in the fact that it represents a technique of organizing a given text, from the part of an author, and an approach towards analyzing and interpreting such a text, from the part of the reader, in order to make a formidable sense of its underlying deep meaning through enabling the reader to form a comprehensive vision that transcends the ability of just knowing that given text; in addition, Leech's model of stylistics stands for an essential path to be taken in order to grasp the pragmatic dimension of the message, from the part of the recipient, that the author of a text may be trying to communicate consciously or subconsciously. Leech's model of stylistics can be used as a method of teaching stylistics as well as an approach to teach literary texts through enabling the learner to make an analogy between how language patterns and norms are used in everyday contexts and those foregrounded (deviated) usages of those same patterns and norms within the literary text, especially poetry with its condensed matrix and the peculiarity of its structure. 
As a result, the main objective of this study emerges as to investigate the applicability magnitude of leech's model of stylistics to a sample literary text, and its credibility - the leech's model -in uncovering what it is proposed to uncover; accordingly, this study bears the limitation of selecting Dylan Thomas's poem "Do Not Go Gentle into That Good Night" because of its representing status to the poetry of Dylan Thomas as a whole, and because of its unique structure and format. Dylan Thomas's poetry, as summarized by the available related literature -Daiches (1954), Olson (1954). Simpson (1979), Jason (1980). Shires (1985), Cabral (1996), Thomas qtd. In Ferris (1977), Tindall, (1996), Hidalgo (1999), Arp, Perrine \& Johnson (2005), Salman, (2008), Valentini (2011), Nagaraju \& Seshaiah (2012). Chew, Song, \& an Argument (2013), Fear (2012). FOI \& POEMA (2013), Ismael (2013), urRehman, (2014). Ackerman, (2016), Jain \& Singh (2016), Mahmood (2017). Ms. Lekha Rani Singh (2017), is generally characterized by its unique linguistic repertoire, its musicality, the originality of its tone, the magnificent rhythm, the telling rhyme scheme, the expressive images, and its original imagery which was distilled from everyday objects and forces of nature to communicate the holiness of the romantic phenomena of nature. The poetry of Dylan Thomas wafts a Welsh aroma and flavour as one can track this influence of Welsh poetical traditions and the Welsh religious atmosphere and rituals, with their senseprovoking sounds, rhythms, cadence, and the musical tone and beat which also radiate a rebellious tendency, within most of his poems; by the same token, it should be added that the poetics and language of Dylan Thomas also carry the influence of the father's tongue, D. J. Thomas, who was an eloquent grammar teacher. Dylan Thomas's poetry is proposed to exploit a wide scope of poetic and linguistic devices, symbols, images, metaphors, verbal patterns, lexis, syntax, rich imagery, extraordinary juxtapositions, strong rhythm and musical beat to communicate a deep meaning in regard to birth, life, love, and the reality of death, which all stand for central themes of Dylan Thomas's poetry. The villanelle matrix, on the other hand, offers a fitting format for the choice of diction, syntax, the construction of the sentence, and the rhyme scheme that mirrors the central themes in Dylan Thomas's poetry; as a result, Dylan Thomas's Poetry is proposed to be difficult to be approach and interpreted because of the uniqueness and, to some extent, the oddity of the poetic style and craft which is immersed in a Welsh linguistic flavor and aroma.

Dylan Thomas's poem "Do Not Go Gentle into That Good Night", as confirmed by Byles (1988), Wang (2006), Zhang, Zhao \& Wang (2008). Chen \& Jacobs, (2010), Terry (2012 ), Chew, Song \& an Argument, (2013), Guo \& Wang (2016), Guo \& Wang (2016), Jain \& Singh, (2016 ), accordingly, within its villanelle matrix, reflects a representing sample of Dylan Thomas's unique poetic style and craft: within this poem, Dylan Thomas exploits different facets of stylistic devices that were enhanced with the set of lexis, patterns of grammar and structure, syntax, metaphor and symbols, sound and phonological paradigms, the rhyme scheme, the musicality of the rhythm, and the appropriate beat and tone which exceptionally have served the general theme of this poem and the message intended to be communicated by Dylan Thomas himself, and, additionally, have deepened the universal meaning of this poem.

A preliminary linguistic scan, by the researcher, of Dylan Thomas's poem "Do Not Go Gentle into That Good Night" reveals that the three maxims of Leech's Model of stylistics (cohesion, foregrounding, and cohesion of foregrounding) are applicable to the poem, and that they-the 
three maxims- can also uncover the aesthetics, the linguistic peculiarity, and the deep meaning and message of this poem as well, but in a connected, direct, and a pithy orientation: cohesion exists mostly in the use of lexis and the grammatical patterns as they came in a repetitive connective order and in a calculable format; foregrounding exists mainly within the lexis of this poem as most word combinations and collocations were used in a deviated, metaphoric, and symbolic coupling; the villanelle matrix of this poem deviates to fit the argumentative and deductive nature of this poem.

The cohesion of foregrounding, which is the third pillar of Leech's model of stylistics, is reflected within the metaphoric technique of giving animate and dynamic attributes to words that normally collocate with inanimate attributes; cohesion of foregrounding is also exhibited through using highly connotative phrases that reflect the underlying cohesive repetitive pattern that goes with the general theme and the intended message of the whole poem; a symbolic cohesive pattern within the foregrounded lexis is also enhanced to mark the idea that a dramatic end governs everything and that mortality can be resurrected if that end is planned to be meaningful and purposeful. The phonological matrix of this poem reveals a cohesive repetitive pattern in the foregrounded sounds such as the use of the $\backslash$ aI $\backslash$ sound, the $\backslash$ eI $\backslash$ sound, the $\backslash \mathrm{i}: \backslash$ sound, the $\backslash \partial \mho \backslash$ sound, and the $\backslash a$ : $\backslash$ sound; this sound scheme goes with the general atmosphere of "death", which is the general theme of this poem, and, in addition, symbolizes the state of mourning of a bereaved soul because of a death occurrence.

\section{Literature review}

The purpose of the following review of the available related literature is mainly aligned to defend and support the argument of this study that Leech's model of stylistics is applicable to Dylan Thomas's poem "Do Not Go Gentle into That Good Night", and, on the other hand, it is workable in revealing different and various layers of the meaning and the message encoded in that poem as well as any other literary text. The following previous review of the available related literature is divided into four sections: the first section defines the Leech's model of stylistics, presents a detailed account about the nature, the components, and the maxims of that model; the second section establishes the rationale of the importance of Leech's model, and the directions of its usability, suitability, and its uniqueness as a linguistic technique which is a applicable to Dylan Thomas's poem "Do Not Go Gentle into That Good Night", as well as other literary or non-literary texts; while the third section generally approaches the linguistic characteristics of Dylan Thomas's poetry, and the scope of its poetics, aesthetics, theme, originality, and the unique structure of that poetry and the special craft; the fourth section sums up what has been found within the available related literature in regard to Dylan Thomas's poem "Do Not Go Gentle into That Good Night", and the uniqueness of its linguistic structure and craft. The following review of the available related literature follows, in a survey-like, a relative chronological format which is meant, and as far as the researcher has been able to, to track the roots of the argument of this study. In addition, the researcher has provided a summary of each section of the review of the available related literature. 


\section{Leech's model of stylistics}

Bodine (1992), as cited in Ayars (2016), explained that "Katie Wales defines cohesion as, "the means (phonological, grammatical, lexical, semantic) of linking sentences into larger units (paragraphs, chapters, etc.), i.e., of making them 'stick together'."'” Leech (1965), as cited in Benham (1996); explained that:

"The three dimensions of his approach are:

(A) Cohesion -- lithe way in which independent Choices in different points of a text correspond with or presuppose One another, forming a network of sequential relations"

(B) Foregrounding: "motivated deviation from Linguistic or other socially accepted norms", and

(C) Cohesion of Foregrounding: "a separate dimension of the descriptive statement, whereby the foregrounded features identified in isolation are related to one another and to the text in its entirety."

Hasan \& Halliday (1976), as cited in Rifqi (2010), stated that "cohesion refers to relations of meaning that exist within the text, and that define it as a text." Leech (1965), as cited in Van Peer, Hakemulder \& Zyngier (2007), "urges us to look for the cohesion of foregrounding: how the different foregrounding elements work together. Obviously, the potential for detecting such cohesion (and being influenced by it) in a single line is highly limited."

McIntyre (2003), mentioned that "foregrounding can be achieved in one of two ways, either via parallelism or by deviation." McIntyre (2003), suggested that "to begin with the first method of achieving foregrounding, linguistic parallelism can be defined as unexpected regularity within a text." McIntyre (2003), explained that "This, then, is foregrounding via linguistic parallelism, but foregrounding can also come about as a result of linguistic deviation. If parallelism is unexpected regularity, then deviation is unexpected irregularity. Deviating from accepted norms also produces a foregrounding effect." McIntyre (2003), as cited in Awonuga, Chimuanya \& Meshioye (2018), further explained that "foregrounding ... refers to those elements of a work of art that stand out in some way. According to Russian formalist scholar at the beginning of the last century, the purpose of art and literature is to defamiliarize the familiar, and by defamiliarizing a work of art or a text we make it stand out from the norm - it becomes foregrounded." Simpson (2004), as cited in Awonuga, Chimuanya \& Meshioye (2018), explained that "Foregrounding: A term borrowed from painting, foregrounding takes two main forms: the deviation-type and the non-deviation type. In other words, it comes in two main guises: foregrounding as deviation from a norm and foregrounding as more of the same." Leech (2007) concluded that "foregrounding: the identification of stylistic effect in what is salient or unexpected or abnormal in the use of language. Examples of norms against which the abnormal may be foregrounded are the twin principles (or maxims) of end focus and of end-weight." Mišśíková (2007) explained that "Foregrounded features in any text are those which break the rules established and respected at any language level. Native speakers of a language, just like many second language learners, recognize these features as odd, stylistically marked and highly expressive. Leech (2014), as cited in Benham (1996), proposes eight types of deviation, categorized and exemplified as follows: 
1) 'Lexical deviation: e.g. Eliot's 'fore suffer' in 'And I Tiresias have fore suffered all'.

2) Grammatical deviation: e.g. 'a grief ago' (Dylan Thomas).

3) Phonological deviation: e.g. "tis' for it is; 'ne'er' for never.

4) Graphological deviation: e.g. e.e. Cumming's orthographic deviation in discarding of capital letters and punctuation.

5) Semantic deviation: e.g. oddity of defining beauty and truth given by Keats in 'Beauty is truth, truth beauty'.

6) Dialectal deviation: e.g. Spenser's use of homely provincial words like 'wimble' (nimble) evoking a "flavor of rustic naivety".

7) Deviation of register (see also Re-registration below): e.g. Eliot's 'The nymphs are departed, have left no address'. Where one can notice juxtaposition of "high-flown poetical diction and stock journalistic phraseology".

8) Deviation of historical period: e.g. Milton's 'inspiring' (=breathing in) and 'induce' (=lead In)."

Yeibo \& Akerele (2014) indicated that "The effectiveness of a given language text, therefore, rests on the oars of form and situation. Generally, textual cohesion is a product of lexical organization. In this vein, the phonological structure of the words that make up a text as a whole contributes to effective transmission of the intended message." Ayars (2016) explained that "combinations and repetitions can be made on all linguistic levels to create both foregrounding (in cases where combinations are unexpected), and cohesion (in cases where the combination is expected)." Ayars (2016), further explained that: "With this theoretical framework, analysis of poetic discourse reveals that parallelism has a dual rhetorical discourse function of back grounding (i.e., cohesion) as well as foregrounding."

Ayars (2016) also added that "Features of Cohesion:

- "Grammatical-syntactic reiteration;

- Lexicogrammatical reiteration, collocation, and parallelism;

- Lexicosemantic reiteration, collocation, and parallelism;

- Pronominal references;

- Conjunctions;

- Ellipsis;"

Leiden: Brill (2013), as cited in Ayars (2016) stated that "cohesion refers to the linguistic phenomena that manifest this conceptual unity... Coherence requires that all elements relate to each other on the basis of a single unifying thread, the theme, or the point of conceptual integration. Cohesion is the tangible evidence of this coherence as it appears in linguistic signals."

Liu (2017) stated that "The notion of foregrounding comes originally from the visual arts and refers to those elements of a work of art that stand out in some way. According to Russian formalist scholars working at the beginning of the last century, the purpose of art and literature is to defamiliarize the familiar, and by defamiliarizing a work of art or a text we make it stand out from the norm - it becomes foregrounded." As cited in Liu (2017), "Foregrounding in linguistics was studied in literary texts in the early twentieth century and was introduced to academics in the West, through translations, by Garvin. Then the theory of foregrounding has its further development in British stylistics, most notably by (Leech (2014). He categorizes prominent linguistic character into two types. One is prominence in quality, and the other is prominence in quantity." 
Yemets (2019) cited that "In reference to literary texts, Leech characterizes Stylistics as the analysis of literary texts, using the linguistic technique (Leech, Geoffrey, 2007). In such case, we deal with Stylistics of literary texts." Yemets (2019), also cited that there are several approaches to the classification of the foregrounding types. The first is suggested by (Leech, Geoffrey, (2007) and involves the division of this device into qualitative and quantitative aspects. The qualitative aspect is the deviation from the language code itself, a breach of some linguistic norm. The quantitative aspect involves the deviation of some expected frequency (Leech \& Short (2007).

Yemets (2019) concluded that "The theory of foregrounding is one of the foundations of Stylistics. The term "foregrounding" was borrowed from the art of painting where the foreground is the part of a painting which is the most prominent in the work of art." As cited in (Yemets (2019), found that "The majority of stylisticians single out two basic principles of foregrounding - deviation and parallelism" (Short (1996); Douthwaite (2000). Deviation can be phonetic, graphological, lexical, grammatical, and semantic (Short (2018). Among the foregrounding techniques related to deviation, (Van Peer \& Hakemulder (2006) mention neologisms, live metaphors, oxymoron, paradox, archaisms, ungrammatical sentences. Parallelism is associated with the quantitative type of foregrounding. It involves the repetition of sentence structure and some words in several sentences. The quantitative aspect can manifest itself in not only syntactical but also lexical and phonetic repetitions. The second approach involves determining the particular techniques of foregrounding. As cited in Ediyono \& Ali (2019), "Foregrounding is a concept that was formerly introduced by Czech theorist Mukařovský \& Garvin (1964), as cited in Miall \& Kuiken (1994) with original term aktualisace and was translated in English into foregrounding. The notion refers to the stylistic variations that can be found in literature, among those literary variations such as alliteration, rhyme (at the phonetic level), inversion and ellipsis (at the grammatical level) and metaphor and irony (at the semantic level)."

To sum up, the previous review stated that Leech's model of stylistics represents a comprehensive approach of using linguistic techniques and description in order to analyze the literary text and then decipher its meaning and message as well. The previous review considers cohesion, foregrounding, cohesion of foregrounding as the main maxims of Leech's model of stylistics: cohesion, as stated by the previous review, refers to the visible and tangible linguistic signals and the organizational network through which the text is weaved and defined, the conceptual unity that exists within the boundaries of the text, the linguistic phenomena that reflects the domain of such a conceptual unity, how the various elements in a text relate to each other, and how they integrate within the text in a unified entity, and, in addition, cohesion refers to the stylistic process of exploiting phonological, grammatical, lexical, and semantic means in order to connect each sentence internally and then connecting sentences together into larger units such as paragraphs or chapters; the previous review also acknowledged variety of features represented by cohesion such as: grammatical-syntactic reiteration, lexical-grammatical reiteration, word collocation, parallelism, lexical-semantic reiteration, pronominal references, conjunctions, and ellipsis; foregrounding, on the other hand, is considered to be as the central component upon which Leech's model of style was built, and can be defined, in accordance with the previous review, as the unexpected combinations that occur in all linguistic levels within the text; this technique of foregrounding can be textually achieved through both deviation and 
parallelism: deviation, as stated by the previous review, represents a qualitative, a metaphoricsymbolic facet through which language rules and norms, code, scheme, are consciously or subconsciously focused on, violated, breached, broken, and disobeyed, by the author, to yield an unexpected, irregular, and to some extent, odd linguistic reality; deviation can be lexical, grammatical, phonological, graph logical, semantic, dialectal, of register, and of historical period. The quantitative facet of foregrounding is parallelism which can be textually manifested through repetition of some foregrounded linguistic features in a relatively calculable format. The previous review considers that the notion of foregrounding was basically borrowed from painting within the arena of art with its binary view to foregrounding - the "deviation-type" and the "non-deviation" type; in this regard, the common ground between literature and art with their interrelated relationship is that the outcome of both goes beyond the regularity and familiarity of the form and context to produce a "de-familiarized" and a foregrounded product against the familiar, normal, and ordinary reality and clichés which can enable the work of art or literature to stand out from the norm. The third pillar of Leech's model of stylistics is labeled as the cohesion of foregrounding which refers to how the different foregrounded elements are subconnected together in a given text, and how they work together within their underlying network to serve a special theme and meaning.

\section{The importance of Leech's model}

Shklovsky (1921), as cited in Hussain \& Saleem (2017), "opines that stylistic devices create a special perception of the object-it creates a 'vision' of the object instead of serving as a means for knowing it" Leech (1965), as cited in Benham (1996), "contends that linguistic description and critical interpretation are "distinct and complementary" ways of explaining literary texts". Leech (1990), cited in Hussain \& Saleem (2017), argues that "foregrounding is the element of surprise and interest which breaks the automatism of everyday usage." In poetry, such artistic deviations "stand out" from the background "like a figure in the foreground of a visual field" Douthwaite (2000), as cited in Yemets (2019), "Foregrounding is the general linguistic technique by which a marked linguistic expression is produced in order to make that expression convey a different meaning than its synonymic equivalent unmarked construction would have conveyed"; Rashid (2001), as cited in McIntyre (2003) discussion of his practice when teaching a lecture course on computing involves many aspects of foregrounding, which he rightly points to as being particularly memorable for his students. McIntyre (2003) suggested that "foregrounding theory, arguably the cornerstone of stylistics, might be employed not only in the analysis of texts but also as a methodology in teaching stylistic analysis. I propose that effective and memorable lectures can be produced by deviating from the supposed prototypical lecture format, and that it is the resultant foregrounding effect that helps to give the lecture its memorable qualities." McIntyre (2003), explained that, "Foregrounding theory was seen as a means of explaining the difference between poetic and everyday language, and despite criticism of this from scholars such as Fish, it has become widely accepted as one of the foundations of stylistics." McIntyre (2003), added that "the important point here is that anything that is foregrounded is highly interpretable and arguably more memorable." McIntyre (2003) confirmed that "many lecturers already make use of foregrounding theory without realizing it." McIntyre (2003), also concluded that "a knowledge of foregrounding theory could 
be extremely valuable for higher education lecturers dealing with large-groups, as it can serve to highlight how the presentation of lecture material can be enhanced, thereby creating a more effective learning experience for the student." Rifqi (2010), concluded that "foregrounding and cohesion are very supportive each other in creating meaning of the examined poem." Leech (2014), as cited in McIntyre (2003), stated that "Foregrounding, or motivated deviation from linguistic or other socially accepted norms, has been claimed to be a basic principle of aesthetic communication." Leech (2014), as cited in Miššíková (2007), added that "foregrounding is a means to achieve a goal: it is the creation of an effect, a special effect, hence a special meaning" Leech, G. N. (2014), cited in Ediyono \& Ali (2019), also added that "The deviation of linguistic elements attributed in literary texts is theoretically called foregrounding; it evokes readers with the analogy of a figure represented by poetical lines." Raj (2016) stated that "Geoffrey Leech aims at relating linguistic description with critical interpretation, and at showing how the latter can benefit from the former". He points out that "a work of literature contains dimensions of meaning additional to those operating in other types of discourse", and he suggests that "for this reason descriptive linguistics cannot simply be applied indifferently as to other types of text." Raj, S. A. (2016), also further explained that "Cohesion: This means the intra-textual relations of a grammatical and lexical kind which knits the parts of a text together into a complete unit of discourse and which, therefore, convey the meaning of the text as a whole. Leech points out that cohesion is the unique property of poetry but is a feature of all types of text since it is this which combines separate linguistic units into stretches of meaning discourse. Foregrounding: This, on the other hand, is a predominantly literary feature. Foregrounding means the deliberate deviation from the rules of the language code or from the accepted conventions of its use that stands out, or is foregrounded, against a background of normal usage. The cohesion of foregrounding: this means the manner in which deviations in a text are related to each other to form inter-textual patterns. These inter-textual patterns are sometimes formed by the cohesion of the foregrounded expressions."

Awonuga, Chimuanya, \& Meshioye (2018) concluded that "The theory of foregrounding is fundamental to the stylistic analysis and interpretation of texts, whether literary or non-literary, in the sense that it underlies our efforts at interpretation. In other words, it is basic to the study of texts. Without engaging the insights that it affords us into the application of linguistic principles to the study of texts, one's interpretation efforts would not amount to much. For it is foregrounding that enables us to account for the textual functions of linguistics and literary patterns that we encounter in our reading in a meaningful manner. It is thus a theory that guides the steps the reader takes in making sense of the text, as stylistic analysis and interpretation is a process." Short (2018), as cited in Miššíková (2007), concluded that "A good starting point for the analysis of any text is to examine the foregrounded parts and provide analysis and interpretation which link those parts together. Foregrounded features are the parts of the text which the author, consciously or unconsciously, is signaling as crucial to our understanding of what he has written..." Ediyono \& Ali (2019), concluded that "a good poetic text observation analysis can be done by examining the important foregrounded parts by author and describe the elements of analysis and interpretation that connect those parts together." Yemets (2019), stated that "The theory of foregrounding was intended to explain and reveal the difference between poetic and everyday language." Yemets (2019), also argued that "it is possible to state that foregrounding is the principle of a literary text organization which focuses the reader's attention on the pragmatically important elements of the message." Haynes, Haynes, Habeshaw, Gibbs \& Habeshaw (2020), as cited in McIntyre 
(2003), "provide many examples of foregrounding being used as a pedagogical technique in large-group teaching."

To sum up, the previous review considered Leech's model of stylistics as an organizing technique from the part of the author to a given text, and a method of stylistically analyzing that text from the part of the reader; as a result, the significance of the Leech's model of stylistics falls in its credibility to orient the attention of the recipient to the pragmatic elements of the author's message, and its suitability as a method of analyzing a given text through spotting the foregrounded features, which the author of a text, consciously or subconsciously, singles out, and, then, steering the reader to a wider scope of understanding and interpretation to that text. The previous review considered that foregrounding, deviation, and cohesion of foregrounding are interrelated and take a complementary mechanism to achieve the goal of uncovering the underlying relationships within a text that create a different and special domain of meaning; and, then, to enable the reader to know the difference between ordinary language patterns and the marked usage of the same language patterns through urging - the reader- to make that kind of analogy between the usual everyday linguistic norms and how they are used within the text, as well as why they are used in that such away. Accordingly, the importance of Leech's model of stylistics lies in the fact that it can also be effectively enhanced as a methodology of teaching the linguistic aesthetics and the stylistics of literary texts, or, even, non-literary texts; this methodology, as stated by the previous review, constitutes a more memorable approach than other methodologies because of its deviated and uncommon nature, and its paradigmatic, connected, and to the point direction. Leech's model of stylistics is also viewed as to be an effective and an aesthetic means of communication that is capable of unveiling the deep meaning of the message that is supposed to be communicated, consciously or subconsciously, by the author of the text. Leech's model of stylistics enables the reader to form a meta-cognitive vision of the text that transcends the level of just knowing it. The applicability of leech's model corresponds to different types of text, but it gains special importance within a literary text because it -the literary text- normally contains various layers of meaning that are very valid whenever and wherever. As a result, the previous review concluded that leech's model, which exploits linguistic description in order to open up the pragmatic gates of a given text, is a very essential path to follow in order to gain more understanding, more volume of interpretation, more opportunity to learn how language works, more comprehensive vision of a given text that transcends the mere knowing about it, and more capability of spotting the difference between everyday language patterns and those marked patterns and structures by the means of foregrounding and deviation. Accordingly, and as stated by the previous review, Leech's Model of stylistics can also serve as a method of teaching literary discourse and genre especially poetry with its peculiarity and speciality, and as a technique of learning aesthetics and the stylistics of the literary text as well. 


\section{The poetry of Dylan Thomas}

Daiches (1954), as cited in Cabral (1996) confirmed that "in spite of recognizing the difficulty with the interpretation of Thomas's poems and the limited number of his themes, images, and phrases, recognize that Thomas's poetry is "magnificent, as well as original in tone and technique, and that he was growing in poetic stature to the last." "Olson (1954), as cited in Cabral (1996), "considered Thomas's poetry very difficult to understand, sometimes seeming irrational, and lacking the necessary discipline." Simpson (1979), as cited in Mohammed (2018), stated that Dylan Thomas's "imagery is drawn from common everyday objects and forces of nature that met his eyes from childhood onwards." Simpson (1979), as cited in Mohammed (2018), added that Dylan Thomas "didn't like Welsh, instead he acquired mastery over English language, but he couldn't escape being influenced by the Bardic traditions of Wales. However, this influence is seen clearly in the choice of words, syntax and in the construction of the sentences, which are often Welsh and not English. This influence is also seen in the technical disciplines controlling sound and rhythm of his poems." Jason (1980), as cited in Chew, Song \& an Argument (2013), argued that "The prescription of death as the defining condition of life in the fixed verse form of the villanelle is apt; the rigidity of the form restricts the poem to exactly nineteen lines marked by two kinds of highly restrictive repetition, reflecting finite existence."

Shires (1985), as cited in Mohammed (2018) concluded that "the strange and intense juxtaposition of adjective and noun, the violence of the imagery, have made many critics confuse Dylan youthful work with surrealist themes." Cabral (1996) explained that death has a fundamental importance in Dylan Thomas' poetry, and the reality of death was his most recurrent theme and concern; studying Thomas's poetry reveals his major attitudes and viewpoints about the reality of death through which he seems to present death as a unifying experience with the natural world, sometimes he seems to suggest a very Christian orthodox concept of resurrection and faith. Sometimes the reality of death is so strong to Thomas that he can perceive it even in the birth of a child, suggesting that there is some sort of unity in the movement of life and death as if they were part of the same process. Thomas's poems suggest an alternative to the menace of death as they entail a reaction and present an affirmative attitude against death. Death threatens the self through terminating the other, in this case, the poet's beloved person, his father, the originator of life, and, in this sense, the menace of annihilating the individual makes death a tragic reality beyond the limits of a natural process. Cabral (1996), added that "Dylan Thomas is one of the most passionate and complex poets of this century. He was exalted because of the exuberance of his rhetoric, his handling of language, the musicality of his poems, the originality of his images, his metaphors, and the mystic impression of his poetry. But he was also criticized because of the excessive concentration of his images, repetitive themes, the complexity of his syntax, taken by some critics as symptoms of superficiality and irresponsibility. His themes are indeed recurrent, but they encompass the elemental experiences of the human existence: birth, life, love, and death, and his treatment of the themes is complex and accurate." Cabral (1996), also added that "Indeed, in reading Thomas's poems one can recognize that he wrote consciously, creating some very complex rhyme schemes, using coherently the verbal patterns and using a very rich imagery, however packed and complex. His poems intend to communicate and they do." Cabral (1996), further concluded that "An important element of the Welsh influence on Thomas is the religious experience which gave him sensibility to the sound of the words, and 
the rhythm of phrases, the cadence, the musical feelings, the impressive rhetoric. The reading of the Bible contributed to enrich Thomas's repertoire of images, as he himself recognized: "the great rhythms had rolled over me from the Welsh pulpits; and I read, for myself, from Job and Ecclesiastes; and the story of the New Testament is part of my life" (Thomas qtd. in Ferris (1977). Tindall (1996), as cited in Mohammed (2018), emphasizes that "Dylan Thomas like the romantics tries to make nature paradise by using nature symbols; his imagery and imagination are influenced by the natural surroundings of his mother country; specially, the beautiful nature, where he spent the early stages of his life. Nature for Dylan Thomas is holy, he finds all nature holy, when he speaks about God or Christ, he has nature in mind or himself, and his holiness is romantic holiness."

Hidalgo (1999), confirmed that "Thomas helps the reader see how life and death dwell together in the same object or Person. Even when something is in its climax of development, he suggests, the seed of decay is at work there." Hidalgo (1999), also added that "Dylan Thomas also shows great faith in man, in his capacity to love, to get outside of himself and to identify with nature and with mankind. Man and his outer world are not isolated entities; they are interrelated for good or bad." Arp, Perrine, \& Johnson, (2005), as cited in Guo, \& Wang (2016), concluded that "The poet can reinforce meaning through sound by choose and group sounds into smooth and pleasant sounding (euphonious) or rough and harsh sounding (cacophonous)." Salman (2008), stated that "Thomas joins words in a highly original way to picture the joyful exhilaration of he the child. He restored to the language of English verse new vigor and freshness after it became hackneyed over centuries."

Valentini (2011) came to the conclusion that "In terms of Thomas' image, the poet serves as an authentic representation of Welsh culture including a very specific literary tradition (the bardic poet) and a profoundly religious (Puritan) perception of the world." Nagaraju \& Seshaiah (2012), as cited in Mohammed (2018), illustrates Dylan Thomas uses symbols and images of nature to express how he feels towards nature, death and childhood. He expresses that, images and symbols are used to create a feeling of love towards life. Also, despite Dylan Thomas" often ambiguous images, he expresses a clear message of nature sacredness."

Chew, Song \& an Argument (2013), explained that "The inevitability of death is a major theme in the villanelle, and Thomas employs the diction of the natural world to anchor our mortality as part of the cosmic order of the universe." Fear (2012), as cited in Foi, \& Poema (2013), "noted that this particular feature in Thomas' poetical work has its roots in his Welsh origins. Although the poet makes use of the English language throughout his work, it is all very steeped in the Welsh tradition: "as a popular saying goes, 'To be born Welsh is to be born privileged, not with a silver spoon in your mouth, but with music in your heart and poetry in your soul." Foi \& Poema, (2013) considered "one of the great poets of the English language from the 20th century, some of his themes and motifs are now often cited as dylanesque: the surreal imagery; the praising of childhood naivete and its imaginative powers in contrast to the pragmatism of adult life, and death as the dissociation of an idealistic childhood. Not to mention the dreamlike word assembling and musical tone, a distinct quality in his poetry." Foi \& Poema (2013) suggested that "The works of Dylan Thomas can be read as an invitation to build and cross bridges between the realms of the real and the imaginary. The literary language enables the artist to create rhythm, images and metaphors, producing a whole new level of communication. And, just like a kid learning through language how to represent everything around, Thomas uses literature as an element of connection to the world-or, 
dare I say, worlds. Thus, literature, to him, represents a device able to gather worlds and languages together."

Ismael (2013), as cited in Mohammed (2018), concluded that "Dylan Thomas symbols are complex and many sided, mostly referring to natural objects." urRehman (2014), as cited in Mohammed (2018), found that "the second element of neo -romanticism in Thomas's poetry is Dylan's longing for his old past. Dylan Thomas expresses his deep longing to his old past days and specially childhood joy and happiness." Ackerman (2016), as cited in Mohammed (2018), shows "that Dylan was the best judge of his own work, he recognized what was original and distinctive in his own verse, he reads only the poems he likes, discarding poems, that didn't meet his chosen criteria. Thomas poetic style was characterized by the development of the image of the various objects and phenomena of nature. The common scene and sights of the country side, are the most influential source of his imagery." Jain \& Singh (2016) concluded that "The theme of all of Thomas's poems is the commemoration of the celestial purpose that he observed in all the human and natural processes. The cycle of love and death, birth and flowering permeate his poems. Thomas was a visionary who saw beyond life and his vision was sensuous and its depiction in the form of poetry appealed aesthetically." Jain \& Singh (2016) also further explained that "he wrote poetry which frequently used the conventional forms of metre, rhyme and rhythm and this appears to symbolize a pleasant return to a former and more contented form of literature. Thomas was among one the modern writers who facilitated the return of English poetry to its roots in its own language. Thomas chose to stir the readers with strong, short words from native English instead of long words derived from foreign languages."

Mahmood (2017), accordingly, stated that Dylan Thomas is described as a unique example of a difficult modernist poet. Not only his style is unique but the subject of his poetry is also unique. Particularly Thomas's poetry is specialized by a dominion theme which is controlled either by birth or death. That is why his early period of writing is called "womb-tomb" era to begin a new technique of writing using his own style and images which are usually called "vibrant images" to convey a complex emotion that matches his philosophical poetry. Mahmood (2017) concluded that "Resembling his father, Thomas inherited the indulgence of reading poetic language especially Shakespeare and thus, he devoted his life in studying literature. Consequently, Thomas fell in love with words and their powerful, vigorous and manifold meanings." Mahmood (2017), also added that "Dylan Thomas tries to scrutinize that life as a cycle in which man cannot fear death. He also tries to inculcate the idea of eternity in the minds of the readers so as to give hope to those miserable souls suffering from the twentieth-century spiritual aridity and the horrors of death represented in two world wars."

Ms. Lekha Rani Singh (2017), as cited in Mohammed (2018), explained that "Dylan Thomas uses symbols that refer to nature such as "green" which means youth, innocence and young age. The expression of nature comes from Dylan's subconscious mind. Thomas frequent observation of immaculate beauty in nature reflects the impact of the neo-romantic movement on him." Çelik (2018) came to the conclusion that "Due to his poetic style which is characterized by his dexterity in establishing imagery, clever word choice, and musicality, it is exceptionally difficult to analyze the poetry Dylan Marlais Thomas." Çelik (2018) added that "the literary career of Dylan Thomas was also a great reflection of his ideas that he so ardently promoted in his poems regarding the life and death. In the earlier works of Thomas, the rebellion in the poet's attitude becomes visible in the tone of his poems as I have demonstrated. It is 
difficult to predict whether it was this rebellion that enabled Thomas to create a base on which he would later adorn his poetry".

Mohammed (2018) stated that "Dylan Thomas is an archetype of modern romanticism, he revolted against the intellectualism and realism of his era of his era and moves to write in the romantic vain of the eighteenth century, with his poetry a new romantic was ushered in, his poetry manifested all the major qualities of neo-romanticism, no wards can express his love for nature, most of his poems are deeply attached with nature." Devi (2019), explained that "Dylan Thomas has rich imagery to his credit. An understanding of his poetry is possible only when we understand his images. His intricate images interact with one another." Devi (2019), added that "Dylan Thomas uses symbols extensively because he seeks to convey complex, psychological states to his readers." Devi (2019), also further explained that "Thomas belongs to the modern age, which is an era of rapid literary change. The poetry of his time is a revolt against tradition resulting largely from the impact of science. The modern poets are more realistic and they rejected the highly ornate and artificial style of an early age. The new poetry is a realistic and the poet's consciousness of the grim realities of life has shattered all illusions and romantic dreams. The new poetry has many innovations to experiment with Impressionism, Imagism, and Surrealism. We can say that Surrealism tinged Dylan's Imagination, though he cannot be labeled a Surrealist."

To sum up, the previous review confirmed the centrality of death as a theme and as a motif all through Dylan Thomas's Poetry; death, in Dylan Thomas's Poetry, represents an essential direction towards defining life itself, while at the same time, it signals a threat to the "self" through annihilating the beloved ones and others; in this sense, death is also seen as a ticking alarm clock to the living because it awakens the self-inner fear about the reality and the inevitability of death, even though it occurs in others; the previous review explained that most of Dylan Thomas's poems invite mortals to always have a reaction against death, and they-the poems- suggest an encountering procedure to the menace of death through rebelliously paving an alternative counter-path in the form of an affirmative attitude against death. The reader of Dylan Thomas's poetry is aided and oriented towards the belief that life and death can be seen to exist together in the same object or person, reflecting a dialectical paradigm about life itself which carries the seed of decay and a ticking clock forwarding towards death. The previous review considered that the horrifying atmosphere of the twentieth century with its two wars affected the climate of Dylan Thomas's poetry, in the sense that his poetry has been seen as an attempt to console the agonized who suffered from the twentieth-century spiritual decay and the commonality of death, and, eventually giving a ray of hope to those enduring miserable souls. The previous review relatively agrees that Dylan Thomas's poetry generally enhances sound techniques to mirror human existence and the rhythmic and fluctuating facets of this existence such as birth (life), love, and death as to be the central drive within the human existence; meaning is totally reinforced through various beats of sound either a smooth and pleasant euphonious sounding or rough and harsh cacophonous sounding. The musicality, the magnificent original tone, the rhythm, and the complex rhyme schemes in Dylan Thomas's poetry are viewed by the previous review as to be a direct yield of the influence of Welsh poetical traditions and, of course, the Welsh religious atmosphere and the Welsh religious rituals with their sense-provoking sounds, rhythms, cadence, and the musical tone which also reflects a rebellious tendency within most of his poems. 
The previous review stated that Dylan Thomas's poetry fosters a wide range of images that were basically conjured from nature with its common scenery and sight of the countryside, especially. Dylan Thomas's images are usually classified as "vibrant images" because of their power to communicate sophisticated emotions that go with the perplexity of the topics and themes of Dylan Thomas's poetry; the scope of Dylan Thomas's imagery pictures his affection to the naivety and the imaginative power of the idealistic childhood against the pragmatic and shabby reality of the adulthood; Dylan Thomas's repertoire of imagery, which had been accumulated from his childhood onward, was originally distilled from nature with its everyday objects and forces to communicate the holiness of the romantic phenomena of nature. Although Dylan Thomas's rhetoric is "buoyant", his language is well-handled, the musicality of his poems is exceptional, the originality of his images is noticeable, his metaphors are rich and unique, and that his poetry carries a mystic tonality, some critics do not celebrate Dylan Thomas's overdependence on images and the repetitive schemes in his poetry. Dylan Thomas's poetry coherently exploits a wide scope of poetic devices and tools such as verbal patterns, choice of words, syntax, rich imagery, extraordinary juxtapositions, complex and multi-towered symbols, striking metaphor, strong rhythm, and an irregular beat to communicate a deep meaning in regard to birth, life, and the reality of death; those poetic devices of Dylan Thomas elevated the level of communication that can enable the reader to cross the bridge in between reality and imagination because they -the devices- represent the complex message that they are supposed covey. Dylan Thomas also exploited the matrix of the villanelle in order to communicate complex messages and powerful meaning in regard to our mortality in connection with the cosmos and universe; the villanelle format offers a fitting space for the choice of diction, syntax, the construction of the sentence, and the rhyme scheme that mirrors the central theme in Dylan Thomas's poetry which is controlled by either birth or death. The previous review acknowledged the difficulty in approaching and interpreting Dylan Thomas's Poetry because of the oddity and uniqueness of the poetic style and craft with their Welsh flavor and aroma; this poetic style facilitated a return to the native roots and origins of the English language as well as a romantic move to early childhood with its atmosphere of joy, happiness, naivety, and purity although scientific revolution, of the twentieth century, has distorted the romantic line in modern life through establishing a taming reality and culture of surrender and submission. Dylan Thomas's poetry celebrates a unified interrelated vision through which life can be understood through death and vice versa; Dylan Thomas's poetry, which was called "womb-tomb" poetry because of the dominion theme which is controlled either by birth or death, reflects a great faith in a human being and his capacities to love, to go out of the boundaries of himself, and, then, to rebel.

\section{Dylan Thomas's poem "Do Not Go Gentle into That Good Night"}

Byles (1988) stated that "the simple theme of "Do not go gentle" is embodied in two rhymed words, "night" and "light": death and life. Do not, he tells his father, accept death quietly, but, raging, affirm life while dying. Yet the night of death is also "that good night:' the rightful end of a natural and inevitable process, and Thomas suggests that even when we rage against it we must accept it. "Good night" is also goodbye, an implicit prayer." Byles (1988) further explained that "The four tercets that 
follow the first speak of four different kinds of men who all meet death in their own ways: "Wise men:' philosophers perhaps, who knowing death "know dark is right:' The "Good men" seem moralists, who having avoided the pleasures of life cannot accept death after such a life. The "Wild men:' lovers of life and action, grieve at the thought of death and dying. "Grave men:' the most important of all and the climax toward which the poet has been writing, are the poets themselves. Grave means serious, concerned intimately with birth, life, and death, whose proximity increases their gravity. But in their closeness to death comes a blinding light, one that ensures vision but also makes it impossible to see."

Wang (2006), as cited in Guo \& Wang (2016), explained that "The first line of this poem "Do not go gentle into that goodnight" is a best example of deviant phrase structure from stylistics. In this sentence, the phrase "go gentle" seems to be a lapse. According to daily usage, the adjective is not proper to be used in a position where an adverbial phrase should be used." Zhang, Zhao, \& Wang (2008), as cited in Guo \& Wang (2016), explained that "The use of repetition of the two refrains "Do not go gentle into that good night" and "Rage, rage against the dying of the light" is one effective device. The two refrains work musical miracles in the poem and keep emphasizing and deepening the theme of the poem."

Chen \& Jacobs (2010), explained that the format of "Do Not Go Gentle into That Good Night", by Dylan Thomas is very similar to the structure of an argumentative, deductive, and persuasive essay; it is an iambic pentameter because it has five beats which follow the unstressed/stressed rhythm, which can be seen in lines such as "Do not go gentle into that good night / Rage, rage against the dying of the light. This poem does have a rhyme scheme that follows the pattern of ABA ABA."

Chen \& Jacobs (2010), also further explains that this first stanza acts like an introduction through which Dylan incites, whoever he is speaking to, to rebel and not give up to death so easily, and instead to "Rage, rage, against the dying of the light" which means to fight against death. The phrases "good night" and "dying of the light" are both metaphors used to represent death; the next four stanzas act like body paragraphs of an essay as they support and backup the introductory first stanza. This argumentative layout of these stanzas concludes that death is unavoidable, and that even people know that death is unavoidable, they still do not give up easily. In the sixth stanza, Dylan speaks only to his father who is on the verge of death to curse or bless him, it doesn't matter as long as his father is alive. Dylan Thomas wrote this poem to persuade his father to not surrender, but to be like other model men who fought against death: First, "Though wise men at their end know dark is right," a metaphor which means that death is unavoidable, yet "they Do not go gentle into that good night"; in other words, this stanza confirms that even though people know that death is unavoidable, still, they do not give up easily. Second, "Good men... crying how bright/their frail deeds might have danced in a green bay." This is another support and a persuasive statement saying that some people feel they have not done enough during their life and could have done more, they "Rage, rage against the dying of the light." Third, "Wild men... learn, too late, they grieved it on its way." This time Dylan is talking about people who have regrets in their life. These men also "Rage, rage against the dying of the light." Fourth, "Grave men, near death, who see with blinding sight," refers to those who are on the verge of death, "see with blinding sight" which suggests that these men are so close to death they start hallucinating and see illuminating images and flashes; but, nevertheless they "Rage, rage against the dying of the light." Dylan uses multiple types of people to communicate the idea that everyone should fight against death and urges his dying father to do the same. Terry (2012), stated that "In his famous 
poem, Dylan Thomas exhorts his aging and ailing father to "not go gentle into that good night" and to "rage, rage against the dying of the light." Chew, Song, \& an Argument (2013), explained that "Do Not Go Gentle into That Good Night" by Dylan Thomas, is a villanelle that encourages men to fight against death, rather than submitting resignedly. Yet, a closer analysis of the form and imagery may reveal that it is because of death, that men are impelled towards living active, purposeful lives - via which their actions attain immortal meaning and thereby overcome death. The villanelle ironically suggests that even as death subjects us to mortality, its very condition of finitude gives meaning to actions by which we may undermine and transcend death's finality.

Guo \& Wang (2016), explained that this poem of Dylan Thomas was written for his father when the father was seriously ill; Dylan's father, D. J. Thomas, was a grammar teacher in a Swansea grammar school, and he was of great influence on Dylan Thomas's poetry; the father D. J. Thomas felt sullen over his whole life and he thought his talent was unrecognized. D. J. Thomas, the father, was eloquent and towered the average in intelligence, but he could not stand out for his sharp words; he was very strong, energetic and militant for the most part of his life, but he became amiable and genial when he got ill. Dylan's father became very different and this was the reason why Dylan urged his father to burn for life, to fight against death before he passed away. "Do not Go Gentle into That Good Night" was written in a villanelle form, which was a traditional poetic form of French; villanelles were popular in the late 1800s and early 1900s in English-language poetry; a villanelle is divided into nineteen lines which comprise five tercets and a quatrain. The rhyme scheme of this poem is ABA ABAABAABAABA ABAA with only two rhymes and there are two refrains. This matrix of this poem - the rhyme scheme and the villanelle format - provided the poet with a suitable framework to model his four characteristic types-wise, good, wild, and grave men-and, in addition, enabled him to equate these types with his father's character. In this poem, both repetition and alliteration are used to give more emphasis to expresses one of the major themes that one should not accept death gently. In the first line "Do not go gentle into that good night", is used to call attention to the words go and good which carry the alliteration, thus giving great emphasis to these words; "Night" symbolizes death, and Night, here, has a negative connotation and the poet adds an adjective "good" to balance this kind of negative effect. This poem was written in a persuasive format as the poet uses deductive reasoning. Dylan Thomas uses "night" as a metaphor for death; then "close of day" and "dying of the light", the synonymous phrases of night are repeated. "Night" is the end of one's life and it represents death, while day is the lifespan of one's life and it represents life. The poet uses dark which is closely related to night as a metaphor for death; "the sun in flight" constitutes a central part of the extended metaphor in which day is a circle of life and the flying of sun represents the bright and beautiful part of life; "The sun in flight" also represents life is short and transient. Dylan Thomas used symbols such as "Good night" which symbolizes death or afterlife; "Close of day" which symbolizes the end of life, and "light" in the "dying of light" which symbolizes life, spirit or soul. In " Do not Go Gentle into That Good Night", Dylan Thomas employed some phonetic and aural devices to convey the general theme of the poem such as using alliteration to emphasize the poet's rebellious urgency that one should not accept death tamely and timidly; monosyllabic words that end with plosives like /d/, /t/ and /k/ t/, in words like "night, old, light, end, dark, right, bright, wild, blind, sad, height," were used throughout the poem because plosives, generally, are 
harsher and sharper in their effect; the cacophonous nature of the plosives and sounds cause a severe feeling. One of the most obvious sound features of this poem is that the poet uses a great amount of "long" vowels or diphthongs like /ai/ and /ei/. E.g. /ai/ night, dying, light, lightening, crying, wild, blinding, blind, eyes, like /ei/ day, age, rave, wave, frail, wage, against, late, grave, blaze; these "long" vowels appear frequently in this poem. Through these vowels, readers could feel that the speaker's voice cracked with grief. Besides, the end rhymes of this poem are /ait/ and lei/. These two rhymes link the keyword of this poem "night" and "day", and "light" and "night" to echo the general theme of this poem. The sound repetition responds to the theme of the poem, and the sound and meaning of "rave", "rage" and "against" shows the rebellious attitude toward death. The poet describes wise men, good men, wild men and grave men's attitudes when they are faced with death. All these men do not accept death submissively and they all rage against death: "Wise men" know death is inevitable and they are wise enough to continue to leave a mark in their life by "their words" which are oriented to influence this world, but regardless the fact that these words failed to make the sought influence on the world, wise men fight against death. "Good men" are about to leave this world, they rage against death by "crying" their deeds may have danced brightly; the image "last wave by" describes how the last wave is about to crash the shore or die; the recent generation is like the wave about to crash onto the shore; the bay is green for it is brimmed with life, plants, and seaweeds. "Grave men are near death, though they could not see clearly, they still try their best to see the world". The poet uses a simile in "Blind eyes could blaze like meteors and be gay" to compares blind eyes of grave men to meteors rather than extinguishing candles; this comparison is ill-matched, and the poet uses this ill-matched comparison on purpose to represent grave men's attitude towards death: though they know they will die, they still see with a twinkle in their eyes and see as much as they can before death. Jain \& Singh (2016), stated that "in Do Not Go Gentle into That Good Night Thomas laid a moving plea to his dying father, which means that "Death" took a new and an intensely personal meaning". The structure of the villanelle points out that it moved down from a choral dance song that goes with its melody and self-improvised lyrics in each stanza. The poem has iambic pentameter and the vocabulary has seven times as many monosyllables as polysyllables. The examples of alliteration are in the following lines: "...blinding sight/ Blind eyes could blaze like meteors and be gay."/ "Do not go gentle into that good night/ Rage, rage against the dying of the light."

To sum up, the previous review acknowledged that "Do Not Go Gentle into That Good Night" mirrors Dylan Thomas's poetic unique style and craft: the theme of this poem, and as stated by the previous review, can be summarized in two words "night" and "light" that symbolize both death and life; within the villanelle matrix of this poem, Dylan Thomas exploits different facets of foregrounding (deviation) in lexis, grammar, syntax, metaphor, the rhyme scheme of this poem, the musicality of the rhythm, and the appropriate beat and tone which exceptionally served the general theme of this poem and the personal message intended to be communicated by Dylan Thomas himself. Dylan Thomas also employed various sound and phonetic devices to convey his rebellious message that one should not accept death timidly and tamely: monosyllabic words that end with plosives like /d/, /t/ and /k/ as "night, old, light, end, dark, right, flight, sight, bright, wild, blind, sad, height", were rendered all through the poem because of their cacophonous nature and their severe, harsher and sharper effect on the recipient's feeling; in addition, Dylan 
Thomas, in this poem, exploited an amount of long vowels or diphthongs like /ai/ in words like "night", "dying", "light", "lightening", "crying", "wild", "blinding", "blind", "eyes", and the diphthong /ei/ in words in words such as "day", "age", "rave", "wave", "frail", "wage", "against", "late", "grave", "blaze"; the frequent use of these long vowels is meant to enable readers of the poem to feel that the speaker's voice is soaked with grief and refusal. Besides, the rhyme scheme of this poem also enhances the two diphthongs of /ai/ and /ei/ within the central words "night", "day", "light", and "night" to go with the general theme of the poem giving a matched effect on the reader. Another phonetic facet in this poem is alliteration which is meant, with its repetitive format especially in words like "rave", "rage" and "against", to emphasize the poet's rebellious message and attitude. The metrical scheme of this poem, an iambic pentameter in five beats which follows the unstressed/stressed rhythm -like a ticking clock and a marching cadence, in lines such as "Do not go gentle into that good night./Rage, rage against the dying of the light," and follows the pattern of ABA ABA, goes with the atmosphere of this poem. Dylan Thomas's "Do Not Go Gentle into That Good Night" is a deductive argumentative poem that is meant to persuade the dying father to rebel against death and not to give up easily, and to follow the example of the four model types of men, wise, good, wild, and grave men, who though know death is unavoidable, but still, they don't surrender easily. Dylan Thomas urges his father to react like those men, in the poem, who fought against death because, simply, everyone should fight against death by leaving behind a meaningful and purposeful mark. In this poem, and as the case is with all Dylan Thomas's Poetry, the previous review uncovered the influence of Dylan Thomas's father, who had been an eloquent grammar teacher, on the poetics and the linguistic stock of Dylan Thomas; moreover, the general atmosphere of this poem bears the shadows of the father's character as D. J. Thomasthe father, had been very strong, energetic, and of military type and character for the most of his life, but, surprisingly, became a different person because of illness and the approaching death.

\section{Applying Leech's model of stylistics on Thomas's poem "Do Not Go Gentle into That Good Night"}

In accordance with the purpose of this study, this section represents a discretionary application from the part of the researcher to check the proposed suitability of the three maxims of Leech's model (cohesion, foregrounding, and cohesion of foregrounding) to Dylan Thomas's poem "Do Not Go Gentle into That Good Night", and to conclude their credibility to unveil the meaning and message of this poem in a unified, connected, and to the point outcome:

Tracking cohesion within Dylan Thomas's poem "Do Not Go Gentle Into That Good Night", it can be stated that both grammatical and lexical cohesion are the most prominent features: grammatical cohesion is obvious in the use of imperative "Do not" and "Rage" in a repetitive pattern all through the poem; the imperative "Do not", which is a form of prohibition, is used in lines $(1+6+12+18)$, and the imperative "Rage" is used in lines $(3+9+15+19)$; the repetitive pattern of these imperatives occurs every three lines alternatively (1-3, 6-9, 12-15), but surprisingly, the imperative "Rage" followed the imperative "Do Not" in the final sixth stanza; this consecutive and foregrounded unification to the two imperatives, in the sixth and final stanza, intensifies the 
deductive argument of the poem, emphasizes the poet's attitude of refusal, and ensures the rebellious message of the poem as a whole.

A similar repetitive pattern is also used with the demonstrative (that) and the definite article (the); (that) is used in lines $(1+6+12+18)$, and (the) is used in lines $(3+9+15+19)$ twice in each line; the repetitive pattern in the use of (that) and (the) also occurs every three lines (1-3,6-9,12$15)$, except for lines $(18,19)$ where they both are used in the same couplet, and where (that) is followed by (the): what can (that) imply is a sense of ambiguity and indefiniteness to what follows, while (the) can imply a sense of definiteness; as a result, the consecutive linkage between (the) and (that) in the last couplet lines(18+19), finally, indicates that the far and ambiguous thing indicated by (that) in line (18) becomes so near and more defined through the double use of (the) in line (19); zero distance separates what was far and indefinite "that good night" and what has become closer, immediate, and definite "the dying of the light." This cohesive usage of (that) and (the) emphasizes the urgency of the moment within the time scope of the poem.

Lexical cohesion, on the other hand, goes with the same mentioned repetitive pattern: the words "gentle" and "good night" occur repetitively within lines $(1,6,12,18)$, while "against" and "dying of light" within lines $(3,9,15,19)$; once again, these phrases were mentioned consecutively within the final couplet -lines $(18,19)$, which indicates the poets' rebellious attitude and refusal in regard to "that good night" and "the dying of light"; semantically both items indicate a final stage or an end: "good night" connotes some kind of departure, and is said when people are preparing to get some sleep at the end of a day when darkness is approaching as the light fades away; accordingly, "the dying of light" is another way to connote "the end of the day". Moreover, the notion of time span is stressed through the selection of words that are semantically related such as: "night", "day", "dark", "light", and "sun"; these words connote the circular shape of a day which begins with light and ends with dark, and so on to represent the circular shape of life itself.

Another form of cohesion within lexis is also enhanced by using the word "men", once again, in a repetitive pattern within lines $(4,7,10,13)$; these lines belong to different stanzas of the whole poem revealing various ideas about those men : "wise men", "good men", "wild men", and "grave men", and each stanza justifies the poet's usage of imperatives "Do not" and "Rage" in a rebellious deductive fashion that goes with the deductive argument of the poem; in addition, stanzas $(2,3,4,5)$ intensify the whole deductive argument as each one of them alternatively contains one of two imperatives "Do not" and "Rage" which were linked with a specific type of men described, but in the sixth and last stanza the two imperatives are linked with the poet's father to signal the personal aspect of the deductive argument which contains two imperatives with two inferences; these two inferences are meant to tell the conditional logic that father is so different in the eyes of poet Dylan Thomas, and, as a result, it is expected that the father must behave differently from those example men mentioned in stanzas $(2,3,4,5)$, and be more courageous to bear the exigency of two dictating imperatives "Do not" and "Rage" .

In this poem, foregrounding is achieved through a parallelistic-repetitive metaphoric paradigm which occurs within the use of lexis and word collocations: For example, in line two "old age" cannot "burn" nor can it "rave" as used in "old age should burn and rave"; "day" is not like a door which can be closed or has " $a$ close" as used in "at close of day"; the light is not able to die as used in "the dying of the light"; "dark" cannot be judged through a right-wrong ends as used in 
"dark is right"; words cannot fork nor "light" can be forked as used in "their words had forked no lightning they"; "frail" barely collocates with "deeds", nor "deeds" have the ability to dance as used in "frail deeds might have danced"; how is it possible to catch and sang the sun? As used in "Wild men who caught and sang the sun"; and how is it possible that the sun be in "flight"? As used in "the sun in flight"; how can someone grieve the sun? As used in "they grieved it on its way"; how is it possible to be near death? As used in "Grave men, near death"; "near" deviates because it is impossible for someone to be "near" death while she $\backslash$ he is still a live; as a result, "near" may describe the circumstances and attributes of someone who is dying like being timid, obedient, and non-rebellious; "see with blinding sight", how is "sight" attributed to be blinding and why? How is it possible to see with such a "blinding sight"? "Blind eyes could blaze like meteors and be gay", blind eyes are able to blaze, and blind eyes are attributed to be "gay"; sadness does have height as used in "sad height"; how tears can be "fierce" as used in "fierce tears". This metaphoric foregrounding is, consciously or subconsciously, meant to achieve an unusual shocking effect on the reader and the recipient of this poem driving them -the reader and recipient- towards forming a vision that correlates with the theme and the rebellious message of the poem.

A parallelistic-repetitive foregrounding also occurs within the phonological mould of this poem: monosyllabic words that end with plosives like /d/, /t/ and /k/ as "night, old, light, end, dark, right, flight, sight, bright, wild, blind, sad, height"; the effect of the plosive nature of these sounds emphasizes the rebellious message that is intended to be communicated by the poet, and to confirm the urgency of time to take action, like a bomb that is ripe enough to explode, in accordance with the imperatives used "Do not" and "Rage"; some long vowels or diphthongs like /ai/ in words like "night", "dying", "light", "lightening", "crying", "wild", "blinding", "blind", "eyes", and the diphthong /ei/ in words in words such as "day", "age", "rave", "wave", "frail", "wage", "against", "late", "grave", "blaze" were also fore grounded against the general atmosphere of the poem so that the reader of the poem can feel the speaker's voice which is soaked with grief and refusal.

Another facet of foregrounding occurs within the villanelle shape of this poem: the sixth stanza is foregrounded against the other five stanzas: the sixth stanza which contains four lines and an (ABAA) rhyme scheme, while the other five stanzas contain three lines each, and a rhyme scheme of (ABA); the sixth stanza deviates in the rhyme scheme, though it obeys the villanelle format, in that it contains two premises and two inferences that go differently, within the deductive argument, from the other five stanzas that contain every two premises and one inference; these two premises two inferences within the sixth stanza came to foreground that the expected response from the father is something extra different from that response from the other types of men mentioned through the previous stanzas because he-the father- has always been different in the eyes of the poet and that the poet (Dylan Thomas) knows how his father had been before being ill and weak.

In this poem, cohesion in foregrounding is achieved through a metaphoric paradigm of giving animate and dynamic attributes to inanimate things: "old age" line (2),"the day" line (2), "light" line (3), "words" line (5), "deeds" line (8), "sun" line (10), "it" line (11),"sight" line (13), "height" line (16), and "tears" line (17) mirror the underlying cohesive pattern of foregrounding as all of these words were given, metaphorically, animate attributes. Cohesion within foregrounding is exhibited through connotative symbolic pattern: foregrounded words like "old age" line (2), "burn" 
line (2), "rave" line (2), "at close of day" line (2), "meteors" line (14) connotatively represent an extinguishing state of being to emphasize the idea that life is also a vanishing state of being; the same connotative pattern is reflected through phrases like "at their end" line (4), "the last wave by" line (7), "too late" line (11), "near death" line (13), and "height" line (15) to indicate the idea that a dramatic end governs everything and life is also governed by the dramatic end in the form of death.

A metaphoric and symbolic cohesive pattern, within the foregrounded lexis, is used to express the end of our life such as "old age" line (2), "close of day" line (2), and "dying of light" line (3) which symbolize death; in addition, the phrases "good night", which is used in a repetitive pattern line $(1,6,12,18)$, and the phrase "dying of light", which is also used in a respective pattern within lines $(3,9,15,19)$ to emphasize the idea that life is no more than a case of suspended death: "old age" is a critical point of time in life as it means that death is approaching afterwards with no escape; the phrase "good night" connotes the same idea as it is normally said to mark people's departure at the end of a day when persons go to sleep, which also symbolizes death; and when light vanishes, in the phrase "dying of light," darkness is actually born and prevails, symbolically, like death with darkness as its main component.

The phonological aspect of this poem reveals a cohesive repetitive pattern in the foregrounded sounds such as \aI \in words like "dying", "right", "bright" , "blinding" , "sight", and "height"; the \eI\sound in words like "frail", "rage", "against", and "blaze"; the $\backslash \mathrm{i} \backslash \backslash$ sound in word

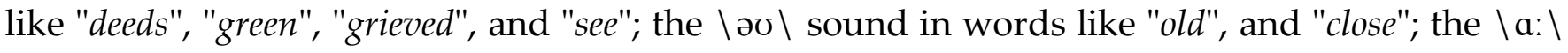
sound in words like "dark" and "danced"; the sharpness and deepness of these sounds go with the general atmosphere of "death", which is the general theme of this poem, coming from bereaved souls, and symbolize the state of mourning a death occurrence.

\section{Discussion}

Although this study was limited in its investigative scope in regard to the magnitude of the applicability of Leech's model of stylistics on one of Dylan Thomas's poems "Do Not Go Gentle Into That Good Night", the application revealed that the three maxims of the Leech's model significantly corresponds to the linguistic structure of this poem, as well as to the underlying meaning and the message of this poem: cohesion was mainly obvious within lexis, grammar, and sound effects of this poem; a repetitive pattern of a calculable format was clear in the usage of lexis and the grammatical patterns used in this poem; this repetitive pattern brilliantly goes with the theme of this poem as to emphasize the state of refusal and the urging rebellious message meant by the poet. The choice of words, such as "night", "day" , "dark", "light", and "sun", came also in a repetitive pattern stressing the time span of the poem and portraying the celestial cycle of life (sun) which normally ends with death (dark); except for the first stanza, the imperatives "Do not" and "Rage" came also in an alternate repetitive pattern: the imperative "Do not" concludes the deductive argument with "Wise men" and "Wild men", and the imperative "Rage" ends the deductive argument with both "Good men" and "Grave men"; "Wise men" and "Wild men", the researcher believes, are coherently connected with the imperative "Do not" as it -the imperativeis the inference to the deductive atmosphere of the stanza which reflects a dimension of failure 
and loss; while the imperative "Rage" is coherently connected with "Good men" and "Grave men", the researcher also believes, to emphasize the idea of urgency and closeness of the moment, and that the action of "raging" must be taken now with no delay . Within the sixth and final stanza, both imperatives " Do not" and "Rage" came, consecutively, in a deviated repetitive pattern, which goes brilliantly with the message of the poem, and which is meant to end the deductive argument with the poet's father; the two consecutive imperatives "Do not" and "Rage" came as two inferences within the deductive context of the sixth stanza so as to emphasize that what is expected from the poet's father is more than what is expected from each type of the men mentioned as example models within stanzas $(2,3,4,5)$.

Foregrounding is carried out through enhancing a parallelistic-repetitive and metaphoric paradigm, which occurs within the use of lexis and word collocations, to achieve an unexpected effect in regard to the general theme and meaning of the poem as a whole, and to focus on the rebellious message intended to be communicated, especially within the sixth stanza which takes a personal and intimate dimension. A parallelistic-repetitive cohesive foregrounding also occurs in the use of monosyllabic words that end with plosives like $/ \mathrm{d} /, \mathrm{t} /$ and $/ \mathrm{k} /$ to also emphasize the rebellious message, and to confirm the urgency of time to take action; within the same pattern, some other long vowels and diphthongs like /ai/, and the diphthong /ei/ were used so that the reader can get into the atmosphere of the poem, and then feel the speaker's voice which is soaked with grief and refusal.

The rhyme scheme of the sixth stanza, though it obeys the villanelle format, deviates from the rhyme scheme of the whole poem as it contains two premises and two inferences, within the deductive format of the whole poem, in an (ABAA) rhyme scheme; these two premises and two inferences, within the sixth stanza, came to foreground the message to the father that the expected response from him must be something extra different from that response expected from the other types of men mentioned through the previous stanzas; this additional and rebellious response from the part of the father is required because he-the father -has always been different in the eyes of the poet, and that the poet (Dylan Thomas) knows how his father had been before being ill and weak.

Cohesion in foregrounding is achieved through a repetitive metaphoric paradigm of giving animate and dynamic attributes to inanimate words; this metaphoric paradigm is meant to result in an unusual shocking effect on the readers and recipients of this poem and to lead them towards forming a comprehensive vision about the theme and message of the poem. Cohesion within foregrounding, which is exhibited through the connotative symbolic pattern in some foregrounded words and phrases, such as "old age" line (2), "burn" line (2), "rave" line (2), "at close of day" line (2), "meteors" line (14), goes also with the general theme and message of the poem: these words symbolize an extinguishing state of being to emphasize the idea that life is also a transitional vanishing state of being. The same connotative pattern is reflected through phrases like "at their end" line (4), "the last wave by" line (7), "too late" line (11), "near death" line (13), and "height" line (15) to symbolize the idea that a dramatic end is a genuine part of everything including life through which death is an absolute part; by the same token, a metaphoric and symbolic cohesive pattern, within the foregrounded lexis, "old age" line (2), "close of day" line (2), and "dying of light" line (3), is tracked to symbolize the idea that death is approaching ; in addition, 
the phrases "good night", which is used in a repetitive pattern lines $(1,6,12,18)$, and the phrase "dying of light", which is also used in a repetitive pattern within lines $(3,9,15,19)$, to emphasize the idea that life is no more than a case of suspended death: "old age" is a critical point of time in a person's life as it means that death is expected to be coming afterwards with no escape; the phrase "good night", which also symbolizes death, connotes the same idea as it is normally said to mark people's departure at the end of a day when persons go to sleep ; and when light vanishes ,in the phrase "dying of light," darkness is actually born and prevails, symbolically, like death with darkness as its main component.

The phonological aspect of this poem reveals a cohesive repetitive pattern in the foregrounded sound such as \aI\ in words like "dying", "right", "bright", "blinding", "sight", and "height"; the \eI\sound in words like "frail", "rage", "against", and "blaze"; the $\backslash \mathrm{i}: \backslash$ sound in word

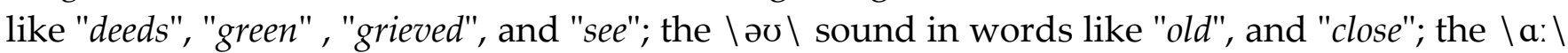
sound in words like "dark" and "danced"; the sharpness and deepness of these sounds go with the general atmosphere of "death", which is the general theme of this poem, coming from bereaved souls, and symbolize the state of mourning a death occurrence.

\section{Findings and conclusions}

The provenance of the aim of this study was to investigate the applicability magnitude of Leech's model of stylistics on Dylan Thomas's poem "Do Not Go Gentle into That Good Night"; and the suitability of this model in revealing different and various aspects of the meaning and message of this poem. Findings of this study indicate that the three maxims of the leech's model of stylistics ( cohesion, foregrounding, and cohesion of foregrounding) are valid and applicable to this poem: cohesion is there mainly in lexis and grammar as most words and grammatical patterns came in a repetitive cohesive mould; foregrounding is exhibited through a metaphoric and symbolic paradigm, sound components - vowels and diphthongs, and the rhyme scheme of this poem; while cohesion of foregrounding is exhibited through using a metaphoric repetitive pattern of giving animate attributes to words that normally collocate with inanimate attributes; a repetitive cohesive pattern is reflected through using a symbolic connotative pattern, and by enhancing a repetitive cohesive pattern within the foregrounded vowels and diphthongs. The findings of this study confirm the suitability of the maxims of leech's model of stylistics (cohesion, foregrounding, and cohesion of foregrounding) to decipher the encoded meaning and message of Dylan Thomas Poem "Do Not Go Gentle into That Good Night", in a short-cut formidable paradigm, contrary to the scattered approach which has been followed by nearly most of the available related literature. The findings of this study agree with the findings of the available related literature that the leech's model of stylistics represents a credible approach to teach stylistics, aesthetics of the literary text especially poetry and an effective means to communicate the pragmatic dimensions of the message indented to be communicated within a given text. Conclusions of this study reflect an agreement with the available related literature about the linguistic uniqueness of Dylan Thomas's poetry in general, and the peculiarity of his Poem "Do Not Go Gentle Into That Good Night" in this regard; in line with its objective, conclusions of this study confirm the uniqueness of the leech's model of stylistics as a well-connected, an 
instructive, a summarized, and a very effective method of approaching literary texts especially poetry; conclusions of this study indicate that linguistic description, which is the core rationale of the leech's model of stylistics, represents an exploitable source to teach English through enabling the learner to make some kind of analogy between the usual usage of linguistic patterns and those foregrounded and deviated patterns in use. Conclusions of this study confirm the suitability of Leech's model of stylistics to unveil different layers of the meaning encoded within the linguistic matrix of Dylan Thomas Poem "Do Not Go Gentle into That Good Night", and to fittingly communicate the elevated message of that poem. Findings of this study indicate that the processes which were followed to approach a literary text, as has been found throughout the available related literature, were scattered in nature, and lacks an adequate competency to interpret various layers of meaning in a unified and a connected account; as a result, conclusions of this study highlights the credibility of the Leech's model of stylistics, as a unified and connected paradigm, to reveal and interpret the meaning encoded within the lines of a literary text, especially poetry, in a unified, direct, interesting, motivating, and instructive procedure.

\section{Recommendations}

In step with the finding and conclusions of this study, and in line with the findings and conclusions of the previous related literature, this study recommends that more empirical studies are highly needed to investigate the effect of analyzing a literary text using Leech's model of stylistics on the capacity of comprehending that text, especially poetry because of its condensed nature and special linguistic structure. This study recommends that further quantitative studies are needed to investigate the effect of enhancing Leech's model of stylistics as a teaching method to teach English language components such as grammar, lexis, syntax, structure, phonetics, and style. This study recommends that further in-depth studies are needed to more investigate the influence of the Welsh tongue on Dylan Thomas's poetry; and, by the same lane, this study recommends that more studies are counseled to shed more light on the moral and the universal message of Dylan Thomas Poem "Do Not Go Gentle into That Good Night". This study also recommends that further studies are desired to investigate quantitatively the effect of enhancing Leech's model of stylistics on elevating the skill of interpreting the literary text depending on its linguistic weave. This study, in addition, recommends applying Leech's model of stylistics to other poems for other poets. This study also recommends that further studies are required to investigate the speciality of the villanelle structure and matrix. This study, finally, recommends more research that investigates the applicability of Leech's model of stylistics to other nonliterary texts.

\section{Conflict of Interest Statement}

The author declares no conflicts of interest. 


\section{About the Author}

Abd-Al-Hameed Mustafa Mahmoud Jabsheh, Lecturer, Department of Languages, Palestine Technical University- Kadoorie (PTUK) \Tulkarm Campus, Palestine. The author has been working as a teacher and lecturer of English Language since 1999; has published some research on English language teaching, linguistics, and literature.

\section{References}

Ackerman, J. (2016). Dylan Thomas: his life and work. Springer.

Arp, T. R., Perrine, L., \& Johnson, G. (2005). Perrine's Sound and Sense: An Introduction to Poetry (School Edition). Heinle \& Heinle Publishers.

Awonuga, C., Chimuanya, L., \& Meshioye, C. (2018). Deviation-type Foregrounding and Literary Interpretation: The Example of James Kirkup's "Thunder and Lightning". International Journal of Language and Literature, 6(1), 69-79.

Ayars, M. I. (2016). The Structure of the Poetic Text: Structural Cohesion and Foregrounding as the Dual Rhetorical Discourse Function of Linguistic Parallelism in Biblical Hebrew Poetry.

Benham, B. (1996). A stylistic study of cohesive features in English prose fiction with some pedagogical implications for non-native contexts (Doctoral dissertation, University of Sheffield).

Bodine, W. R. (Ed.). (1992). Linguistics and Biblical Hebrew. Eisenbrauns.

Byles, J. M. (1988). The poetry of Dylan Thomas: origins and ends of existence. Syracuse Scholar (1979-1991), 9(2), 8.

Cabral, G. D. S. (1996). Death in the poetry of Dylan Thomas. https://repositorio.ufsc.br/xmlui/handle/123456789/158058.

Çelik, A. (2018). The Poetic Language of Life and Death in Dylan Thomas. (Senior Thesis). https://d1wqtxts1xzle7.cloudfront.net/63055508/Senior Thesis Arda20200422516336v8g bkwithcoverpagev2.pdf?Expires=1644679278\&Signature=AjvC9s1M36iXgRqjDD5SaVKz 68cO8NRfKn9CZ4J9CzFOJePc3zWFaCN4gxygVMJa0tWXG41 rVooRevSa A3EDfttklT Wi1mhICqRNxqewPFsNTWXhbxC qVE5DCSEXggNGDWXJ99Hp3Fr0vBMjwEV3UXp Mj4FeEzKNehVsqr5RrEghVjnYPLx8a9rbIAJe2nq8FOKpCc3rJ4K147t941xebwuMCwhoa UypGLpXC0KuNm35Jc1b4WPLFYqyNyYbn1OHcmywIBoyc4jQK8pWFfO3GP4ie1vtQ p4KRizRpH2QY7wikih8p5h23apD3ns1RIEFrTENThYQXAvWtEBA \&KeyPairId=APK AJLOHF5GGSLRBV4ZA

Chen, A. Prof. Jacobs English 165W September 23, 2010.

Chew, H., Song, G., \& an Argument, C. (2013). Do Not Go Gentle into That Good Night.

Daiches, D. (1954). The Poetry of Dylan Thomas. College English, 16(1), 1-8.

Devi, S. K. C. (2019). Dylan Thomas As a Poet. https://www.rjoe.org.in/Files/VOL4ISS3/RJOESRR CRR 275-278.pdf

Douthwaite, J. (2000). Towards a linguistic theory of foregrounding. Ed. dell'Orso.

Ediyono, S., \& Ali, S. (2019). Foregrounding and Metaphor: A Stylistic Study on Hamza Yusuf's Religious Poems. Theory and Practice in Language Studies, 9(6), 746-753. 
Fear, A. P. (2012). A walk through Llareggub: a reading of Dylan Thomas's Under milk wood. https://www.lume.ufrgs.br/handle/10183/54092

Ferris, P. (1977). Dylan Thomas. Dial Press.

Fitz Gibbon, C. (1965). The Life of Dylan Thomas (Vol. 174). Little, Brown.

Foi, E., \& Poema, U. (2013). 2 This Story I Write Was Once a Poem: Themes in Motion in Dylan Thomas' prose and Poetry.

Guo, L., \& Wang, L. (2016). Poetic Analysis on "Do not Go Gentle into That Good Night". Humanities and Social Sciences, 4(4), 127.

Hasan, R., \&Halliday, M. (1976). Cohesion in English. Tạp Chí Nghiên Cúu Nước Ngoài, 181.

Haynes, A., Haynes, K., Habeshaw, S., Gibbs, G., \& Habeshaw, T. (2020). 53 Interesting Things to do in your Lectures: Tips and strategies for really effective lectures and presentations. Routledge.

Hidalgo, M. D. L. Á. C. (1999). Confronting opposites optimistically with Dylan Thomas. Revista de Filología y Lingüística de la Universidad de Costa Rica, 25(1), 143-150.

Hussain, R., \&Saleem, A. (2017). Modernism and Postmodernism Foregrounded: A Stylistic Analysis of EE Cummings Poems. Putaj Humanities $\mathcal{E}$ Social Sciences, 24(2).

Hussein, K. (2012). Linguistic foregrounding through internal deviation. Digital version available at: https://www.researchgate.net/publication/316118880/download, 1-27.

Ismael, N. A. (2013). Dylan Thomas: The Vision of Death as a Prologue to a New Life. Journal of the College of Languages (JCL) Mă̆allä̈kulliyyä̈ al-luğāt, (27), 1-13.

Jain, U., \& Singh, R. (2016). The use of aesthetic symbols and imagery in the poems of Dylan Thomas. International Journal of English Language, Literature in Humanities, 4(4), 456.

Jason, P. K. (1980). Modern Versions of the Villanelle. College Literature, 7(2), 136-145.

Leech, G. (1965). This Bread I Break: Language and interpretation. Review of English Literature, 6(2), 66-75.

Leech, G. (1990). N. (1969). A Linguistic Guide to English Poetry. London and New York: Longman.

Leech, G. N., \& Short, M. (2007). Style in fiction: A linguistic introduction to English fictional prose (No. 13). Pearson Education.

Leech, Geoffrey (2007). Language in Literature: Style and Foregrounding.

Leech, G. (2007). Style in fiction revisited: the beginning of Great Expectations. Style, 41(2), 117132.

Leech, G. N. (2014). A linguistic guide to English poetry (Vol. 4). Routledge.

Leech, G. (2014). 'This bread I break'-language and interpretation. In Language in Literature (pp. 40-48). Routledge.

Leiden: Brill. Geoffrey Khan. (2013). Robar, Elizabeth. "Coherence and Cohesion". Pages 473-476 in The Encyclopaedia of Hebrew Language and Linguistics. Vol. 1.

Liu, S. (2017, September). A Study of the Foregrounded Features in English Advertising Texts. In 3rd Annual International Conference on Social Science and Contemporary Humanity Development (SSCHD 2017). Atlantis Press.

Mahmood, W. S. (2017). Thematic analysis in two poems written by Dylan Thomas. مجلة العلوم

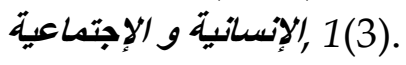

McIntyre, D. (2003). Using foregrounding theory as a teaching methodology in a stylistics course. Style, 37(1), 1-13. 
Miall, D. S., \& Kuiken, D. (1994). Foregrounding, defamiliarization, and affect: Response to literary stories. Poetics, 22(5), 389-407.

Miššíková, G. (2007). Pragmatic dimensions in stylistic analysis. https://digilib.phil.muni.cz/bitstream/handle/11222.digilib/104432/1 BrnoStudiesEnglish 33-2007-1 8.pdf?sequence=1

Mohammed, M. Y. (2018). Dylan Thomas as Neo Romantic Poet. https://www.uoanbar.edu.iq/HumanitarianEducationCollege/catalog/5mohammeed.pdf Ms. Lekha Rani Singh (2017). Appreciation of Beauty and Nature in the poems of Dylan Thomas. IOSR Journal of Humanities and Social Science (IOSR-JHSS), vol. 22, no. 9, pp. 26- 29

Mukařovský, J., \& Garvin, P. L. (1964). A Prague School reader on esthetics, literary structure, and style. Standard language and poetic language, 17-30.

Nagaraju, C., \& Seshaiah, K. V. (2012). A study of Dylan Thomas's poetry. IOSR Journal of Humanities and Social Science, 6-10.

Olson, E. (1954). The Poetry of Dylan Thomas [Review of The Collected Poems of Dylan Thomas, by D. Thomas]. Poetry, 83(4), 213-220. http://www.jstor.org/stable/20585195

Raj, S. A. (2016). Multi-Visions in English Language \& Literature. EduPedia Publications (P) Ltd.

Rashid, A. (2001). Lecturing to Large Groups: Good Practice Guidelines. Tall Tales.

Rifqi, M. (2010). Foregrounding And Cohesion in Philip Larkin's Poem' the North Ship'. Lite: Jurnal Bahasa, Sastra, dan Budaya, 6(1), 1-13.

Salman Sirhan, Q. (2008). The Secularization of Christian Imagery in Dylan Thomas's Poetry. Journal of Al-qadisiya in arts and educational science, 8(1), 3-9.

Shapiro, K. (1955). Dylan Thomas. Poetry, 87(2), 100-110. http://www.jstor.org/stable/20585876 Shires, L. (1985). British Poetry of the Second World War. Springer.

Shklovsky, V. (1921). Sterne's Tristram Shandy: stylistic commentary. The Novel: An Anthology of Criticism and Theory 1900-2000, 31-53.

Short, M. (2018). Exploring the language of poems, plays and prose. Routledge.

Short, M. (1996). Learning About Language. Exploring the Language of Poems, Plays and Prose.

Simpson, L. (1979). Studies of Dylan Thomas, Allen Ginsberg, Sylvia Plath and Robert Lowell. Springer.

Simpson, P. (2004). Stylistics: A resource book for students. Psychology Press.

Terry, K. S. (2012). Do Not Go Gentle: Using Emeritus Pro Bono Attorneys to Achieve the Promise of Justice. Geo. J. on Poverty L. EPol'y, 19, 75.

Tindall, W. Y. (1996). A reader's guide to Dylan Thomas. Syracuse University Press.

urRehman, M. (2014). Dylan Thomas' "Fern Hill”: A Desire to Reach the Real from The Symbolic, A Lacanian Reading of The Poem. Gomal University Journal of Research, 30, 1.

Valentini, R. (2011). The rage against the dying of the light (Doctoral dissertation, Uniwien).

Van Peer, W., \& Hakemulder, J. (2006). Foregrounding.

Van Peer, W., Hakemulder, J., \& Zyngier, S. (2007). Lines on feeling: Foregrounding, aesthetics and meaning. Language and Literature, 16(2), 197-213.

Wang, S. (2006). Essentials of English stylistics. 山东大学出版社.

Yeibo, E., \& Akerele, C. (2014). Phonological foregrounding in Chimamanda Adichie's Purple hibiscus. International Journal of language and linguistics, 1(2), 61-71. 
Yemets, A. (2019). Types and Functions of Foregrounding in the Contemporary Flash Fiction Stories.

Zhang, J., Zhao, D., \& Wang, W. (2008). Selected readings in British and American poetry.

Author(s) will retain the copyright of their published articles agreeing that a Creative Commons Attribution 4.0 International License (CC BY 4.0) terms will be applied to their work. Under the terms of this license, no permission is required from the author(s) or publisher for members of the community to copy, distribute, transmit or adapt the article content, providing a proper, prominent and unambiguous attribution to the authors in a manner that makes clear that the materials are being reused under permission of a Creative Commons License. Views, opinions and conclusions expressed in this research article are views, opinions and conclusions of the author(s). and European Journal of Literature, Language and Linguistics Studies shall not be responsible or answerable for any loss, damage or liability caused in relation to/arising out of conflicts of interest, copyright violations and inappropriate or inaccurate use of any kind content related or integrated into the research work. All the published works are meeting the Open Access Publishing requirements and can be freely accessed, shared, modified, distributed and used in educational, commercial and non-commercial purposes under a Creative Commons Attribution 4.0 International License (CC BY 4.0). 